\title{
Pengembangan Sistem Monitoring Inkubator Bayi Prematur Secara Real Time Menggunakan Android
}

\author{
Kiki Anggara ${ }^{1 *}$, Faisal Hadi, S.T., M. T. ${ }^{2 *}$ Junas Haidi, S.T., M. T. ${ }^{3 *}$ \\ ${ }^{1}$ Program Studi Teknik Elektro, Fakultas Teknik, Universitas Bengkulu,Kota Bengkulu,Provinsi Bengkulu \\ *Kanggara743@gmail.com
}

\begin{abstract}
ABSTRAK
Bagi orang tua masalah kesehatan buah hati merupakan suatu hal yang sangat penting. Terlebih lagi bagi orang tua yang kurang beruntung melahirkan bayi dalam keadaan kurang sehat atau prematur menurut dokter, sehingga diperlukan perawatan menggunakan inkubator. Inkubator bayi adalah sebuah wadah tertutup yang kehangatan lingkungannya dapat diatur dengan cara memanaskan udara dengan suhu tertentu, yang berfungsi untuk menghangatkan bayi. Thingspeak adalah platform open source Internet of Things (IoT) aplikasi dan API untuk menyimpan dan mengambil data dari hal menggunakan protokol HTTP melalui Internet atau melalui Local Area Network. ThingSpeak memungkinkan pembuatan aplikasi sensor logging, aplikasi lokasi pelacakan, dan jaringan sosial. Berdasarkan perancangan yang dilakukan untuk penerapan sistem monitoring inkubator bayi prematur secara real time dengan menggunakan android tidak berjalan sesuai dengan yang diinginkan, karena memiliki delay waktu sebesar 10-15 detik. Pengaplikasian android sebagai sistem monitoring jarak jauh menggunakan kamera dilakukan dengan aplikasi GoPLus Cam. Aplikasi GoPlus Cam android dan kamera memiliki jarak koneksi maksimum yaitu jarak $15 \mathrm{~m}$. Pengaplikasian android sebagai tampilan output suhu, detak jantung dan berat badan ditampilkan menggunakan aplikasi thingshow. Aplikasi thingshow menampilkan pembacaan data suhu dan detak jantung dalam bentuk grafik sedangkan pembacaan berat badan ditampilkan dalam bentuk angka dan berhasil ditampilkan pada android.
\end{abstract}

Kata Kunci : Monitoring Inkubator Bayi, Thingspeak,

\section{NodeMCU ESP8266}

\section{Pendahuluan}

Bagi orang tua masalah kesehatan buah hati merupakan suatu hal yang sangat penting. Terlebih lagi bagi orang tua yang kurang beruntung melahirkan bayi dalam keadaan kurang sehat atau prematur menurut dokter, sehingga diperlukan perawatan menggunakan inkubator. Persalinan prematur merupakan proses persalinan sebelum usia kehamilan mencapai 37 minggu lengkap atau kurang dari 259 hari, yang dihitung dari hari pertama haid terakhir. Jika usia kehamilan tak diketahui dengan pasti, maka yang menjadi patokan adalah berat bayi saat lahir yang hanya berkisar 1.000 - 2.500 gram. Inkubator berfungsi menjaga temperatur bayi supaya tetap stabil yaitu antara $32{ }^{\circ} \mathrm{C}-37,5^{\circ} \mathrm{C}$.

Bayi prematur pada umumnya perlu diletakkan di inkubator dengan temperatur ruangan yang terkontrol, sehingga bayi tetap berada pada temperatur yang sesuai saat bayi berada dalam kandungan. Faktor-faktor yang perlu diperhatikan pada inkubator adalah temperatur inkubator dan temperatur bayi. Kebanyakan orang tua lebih memilih merawat bayinya dirumah meskipun harus menggunakan inkubator, sehingga kini muncul gagasan baru dalam sistem pelayanan rumah sakit yaitu penyewaan inkubator. Dengan sistem ini orang tua dapat merawat bayinya dirumah sendiri dengan inkubator dengan harga sewa yang cukup mahal [1]

Salah satu tempat untuk meletakkan bayi adalah inkubator bayi. Inkubator bayi adalah sebuah wadah tertutup yang kehangatan lingkungannya dapat diatur dengan cara memanaskan udara dengan suhu tertentu, yang berfungsi untuk menghangatkan bayi. Inkubator bayi memiliki beberapa parameter yaitu, temprature, kelembaban, air flow, dan noise. Tingkat kelayakan kebocoran suhu luar $\pm 1^{\circ} \mathrm{C}$, tingkat kelembaban antara $\geq$ $70 \%$, laju aliran udara $<0,35 \mathrm{~ms}$ dan tingkat kebisingan di dalam inkubator $<60 \mathrm{dBA}$. Persyaratan tersebut harus terpenuhi untuk mendapatkan kriteria keselamatan dan keamanan dalam penggunaannya [2].

Pada penelitian sebelumnya perancangan prototype sistem pengaturan suhu dan kelembaban inkubator berdasarkan umur dan berat badan bayi menggunakan fuzzy logic control. Berdasarkan umur dan berat bayi sebagai inputan untuk pengaturan suhu dan kelembaban menggunakan fuzzy logic control, dapat dicapai kesusaian suhu dan kelembaban yang dibutuhkan bayi di dalam inkubator. Penelitian sebelumnya hanya fokus pada pengontrolan menggunakan metode fuzzy logic 


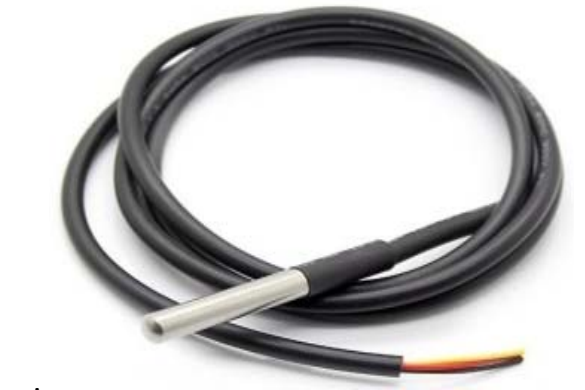

Gambar 1. Sensor DS18B20[12]

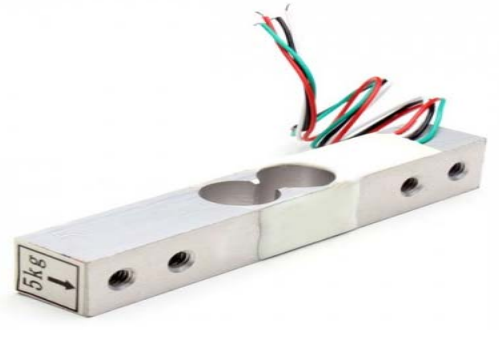

Gambar 2. Sensor Load cell[13]

control. Berdasarkan hal tersebut maka untuk pengembangan penelitian selanjutnya tentang pengembangan sistem monitoring menggunakan android.

\section{TINJAUAN PUSTAKA}

Beberapa peneliti sebelumnya mengkaji tentang monitoring inkubator bayi. Ilham Aswan, Yenisa Intan Ramadhani, Salahuddin Nur Sultan, Aryanti Febri, dkk, Daniel Priyo Yuwono, Budhi Kristianto, Novika Sari $[1][3][4][5][18]$.

\section{A. Inkubator Bayi}

Inkubator bayi adalah suatu kotak yang dirancang untuk mempertahankan suhu internal yang konstan dengan mengunakan termostat (thermostat)[7]. Bayi prematur mempunyai kesulitan mempertahankan suhu tubuh yang tetap dan mudah terjadi variasi[8]. Bayi yang baru lahir di Indonesia mempunyai dimensi fisik rata-rata dengan panjang $55 \mathrm{~cm}$, lebar dada bayi $45 \mathrm{~cm}$,dan berat bayi $3 \mathrm{~kg}[9]$.

\section{B. Sensor DS18B20}

Sensor DS18B20 merupakan sensor suhu yang berbentuk rangkaian terintegrasi dan memiliki output berupa bilangan biner yang berubah secara linear dan proporsional terhadap suhu atau temperatur. Sensor ini akan digunakan sebagai pembaca suhu tubuh pada bayi[12].

Sensor suhu DS18B20 membutuhkan tegangan DC 3 sampai 5,5 volt dalam beroprasi. Bentuk fisik sensor suhu DS18B20 berupa chip IC dengan kemasan yang bervariasi, dan yang digunakan pada pengukuran

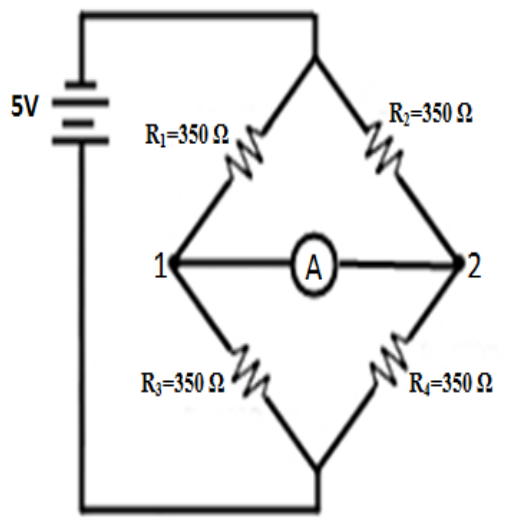

Gambar 3. Rangkaian Jembatan Wheatstone Tanpa Beban[14]

suhu tubuh bayi ini adalah kemasan waterproof (anti air). Pada umumnya kemasan sensor suhu DS18B20 adalah kemasan TO-92. Adapun bentuk fisik dari perangkat sensor DS18B20 dapat dilihat pada Gambar 1.

Dari Gambar 1 dapat di ketahui bahwa sensor suhu DS18B20 pada dasarnya memiliki 3 pin yang memiliki fungsi sebagai sumber tegangan $\mathrm{DC}+5$ volt, sebagai pin output hasil pengindraan (data) dan pin untuk grond[12].

Sensor suhu DS18B20 memiliki keakuratan tinggi dan mudah dalam perancangan jika dibandingkan dengan sensor suhu yang lain. Keluaran pada sensor ini memiliki impedansi yang rendah dan linieritas yang tinggi sehingga dapat dengan mudah dihubungkan dengan rangkaian kontrol khusus serta tidak memerlukan pengaturan tambahan.

Sensor suhu DS18B20 memiliki jangkauan pengukuran $-55^{\circ} \mathrm{C}$ hingga $+125^{\circ} \mathrm{C}$ dengan akurasi $\pm 0.5^{\circ} \mathrm{C}$ namun disarankan agar tidak melebihi $+100{ }^{\circ} \mathrm{C}$ untuk menghindari kerusakan pada sensor. Sensor ini memiliki 9-12 bit data yang dapat dikonfigurasi [12].

\section{Load Cell}

Sensor load cell merupakan sensor regangan yang mempunyai prinsip kerja ketika bagian lain yang lebih elastis mendapat tekanan, maka pada sisi lain akan mengalami perubahan regangan yang sesuai dengan yang dihasilkan oleh straingauge. Hal ini terjadi diakibatkan oleh perubahan gaya diubah menjadi nilai tegangan oleh rangkaian pengukuran yang ada. Berat objek yang diukur dapat diketahui dengan mengukur besarnya nilai tegangan yang timbul.

Adapun bentuk fisik dari sensor load cell dapat dilihat pada Gambar 2[13].

Load cell adalah komponen utama pada sistem timbangan digital. Sensor load cell apabila diberi beban 


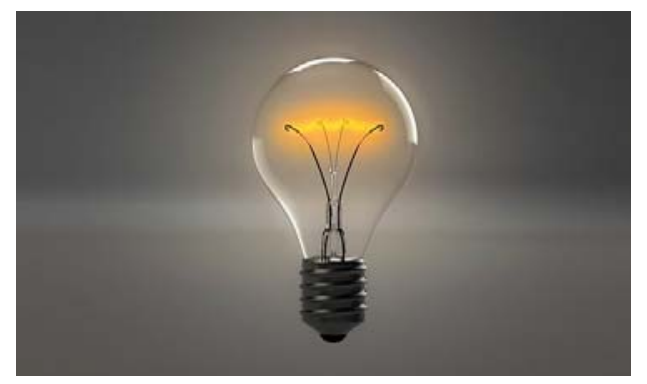

Gambar 4. Lampu Pijar[1]

pada inti besi maka nilai resistansi yang ada di strain gauge akan berubah. Sebuah load cell terdiri dari konduktor, strain gauge dan jembatan wheatstone[13].

Selama proses penimbangan akan mengakibatkan reaksi terhadap elemen logam pada load cell yang mengakibatkan gaya secara elastis. Gaya yang ditimbulkan oleh regangan ini dikonversikan kedalam sinyal elektrik oleh strain gauge (pengukur regangan) yang terpasang pada load cell. Prinsip kerja load cell berdasarkan rangkaian Jembatan Wheatstone dapat dilihat pada Gambar 2.3[15].

Pada Gambar 3 nilai $\mathrm{R}=350 \Omega$, arus yang mengalir pada R1 dan R3 sama dengan arus yang mengalir di R2 dan R4, hal ini dikarenakan nilai semua resistor sama dan tidak ada perbedaan tegangan antara titik 1 dan 2, oleh karena itu rangkaian ini dikatakan seimbang. Untuk rangkaian jembatan wheatstone dapat dilihat pada Gambar 2.11.

Rangkaian jembatan Wheatstone yang diberi beban seperti Gambar 2.14, akan menyebabkan nilai $\mathrm{R}$ pada rangkaian akan berubah, nilai R1=R4 dan R2=R3. Sensor load cell tidak dalam kondisi yang seimbang dan membuat beda potensial. Beda potensial inilah yang menjadi output-nya.

Secara teori, prinsip kerja load cell berdasarkan pada jembatan Wheatstone dimana saat load cell diberi beban terjadi perubahan pada nilai resistansi, nilai resistansi R1 dan R3 akan turun sedangkan nilai resistansi R2 dan R4 akan naik. Pada posisi setimbang,

Vout load cell $=0$ volt, namun ketika nilai resistansi R1 dan R3 naik maka akan terjadi perubahan Vout pada load cell. Load cell output data $(+)$ dipengaruhi oleh perubahan resistansi pada R1, sedangkan output (-) dipengaruhi oleh perubahan resistansi R3[13].

\section{E. Lampu Pijar}

Lampu Pijar atau disebut juga Incandescent Lamp adalah jenis lampu listrik yang menghasilkan cahaya dengan cara memanaskan Kawat Filamen di dalam bola kaca yang diisi dengan gas tertentu seperti nitrogen, argon, kripton atau hidrogen. Kita dapat menemukan Lampu Pijar dalam berbagai pilihan Tegangan listrik yaitu Tegangan listrik yang berkisar dari $1,5 \mathrm{~V}$ hingga $300 \mathrm{~V}$.
TABEL 1

DETAK JANTUNG NORMAL PADA BAYI DAN ANAK

\begin{tabular}{ccc}
\hline No & Usia & Detak Jantung \\
\hline 1. & Bayi Baru Lahir & $70-190 \mathrm{Bpm}$ \\
2. & 1-11 Bulan & $70-150 \mathrm{Bpm}$ \\
3. & 1-2 Tahun & $70-130 \mathrm{Bpm}$ \\
4. & 3-4 Tahun & $70-120 \mathrm{Bpm}$ \\
5. & 5-6 Tahun & $70-115 \mathrm{Bpm}$ \\
6. & 7-9 Tahun & $70-110 \mathrm{Bpm}$ \\
7. & > 10 Tahun & $60-100 \mathrm{Bpm}$ \\
\hline
\end{tabular}

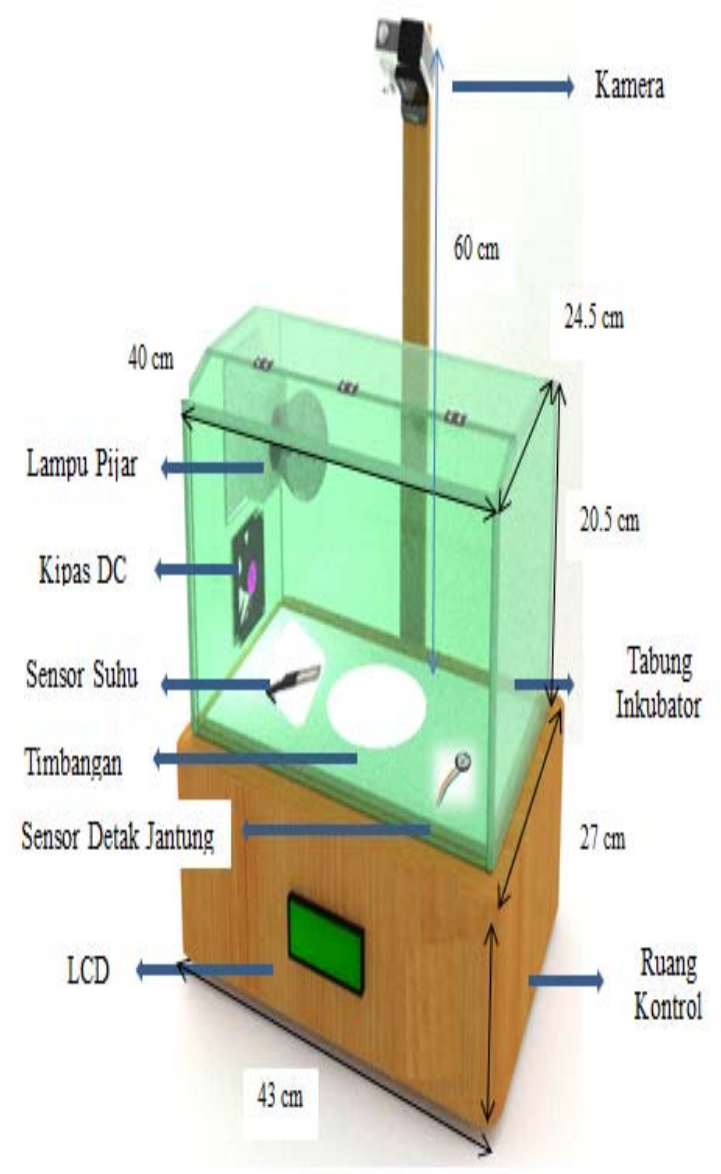

Gambar 5. Tabung Inkubator Keseluruhan

Lampu Pijar yang dapat bekerja pada Arus DC maupun Arus AC ini banyak digunakan di Lampu Penerang Jalan, Lampu Rumah dan Kantor, Lampu Mobil, Lampu Flash dan juga Lampu Dekorasi. Pada umumnya Lampu Pijar hanya dapat bertahan sekitar 1000 jam dan memerlukan Energi listrik yang lebih banyak dibandingkan dengan jenis-jenis lampu lainnya. Gambar fisik lampu pijar dapat dilihat pada Gambar 4. 


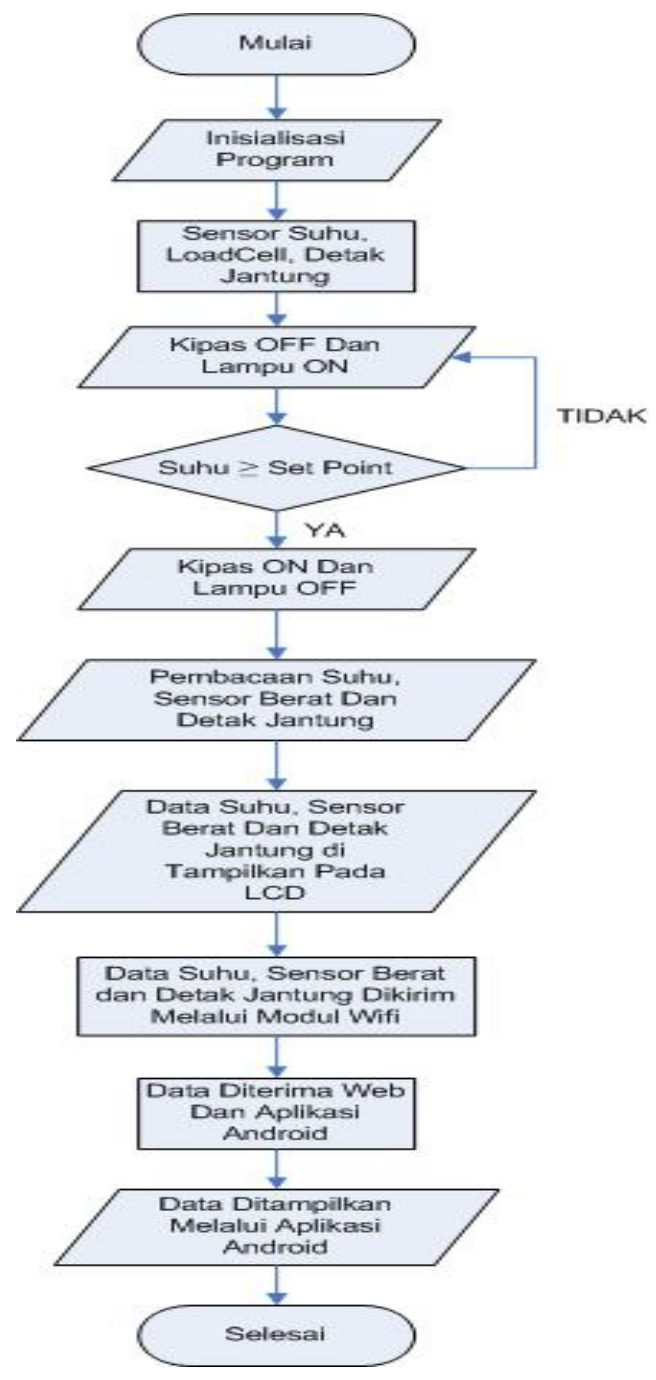

Gambar 11. Diagram Alir Sistem Monitoring Inkubator Bayi

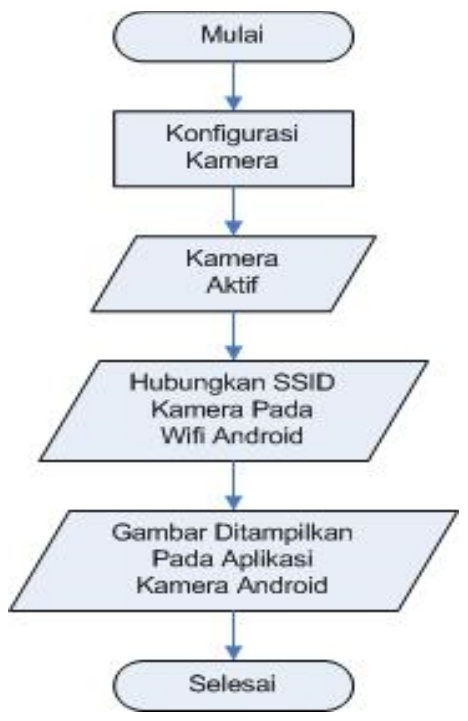

Gambar 12. Diagram Alir Sistem Monitoring Kamera
TABEL 3

PENGUJIAN LOAD CELL DENGAN VARIASI BERAT

\begin{tabular}{ccc}
\hline $\begin{array}{c}\text { Objek } \\
\text { Ke- }\end{array}$ & $\begin{array}{c}\text { Timbangan } \\
\text { (Kg) }\end{array}$ & Load Cell \\
\hline 1. & 0,00 & 0,00 \\
2. & 1,00 & 1,10 \\
3. & 1,50 & 1,67 \\
4. & 2,00 & 2,20 \\
5. & 2,50 & 2,65 \\
6. & 3,00 & 3,15 \\
7. & 3,50 & 3,70 \\
8. & 4,00 & 4,18 \\
9. & 4,50 & 4,80 \\
10. & 5,00 & 5,28 \\
\hline
\end{tabular}

\section{METODE PENELITIAN}

\section{A. Perancangan Sistem}

Rancangan penelitian yang akan dilakukan terdiri dari beberapa tahap perancangan yaitu tahapan pembuatan perangkat keras (hardware) dan tahapan perancangan perangkat lunak (software). Pada bagian ini akan menjelaskan perancangan secara umum dari prototype sistem monitoring inkubator bayi prematur yang diinginkan. Perancangan meliputi diagram blok sistem yang diinginkan, sehingga setiap komponen yang membangun miniatur sistem monitoring inkubator bayi prematur ini bisa tergambar lebih jelas.

\section{B. Blok Diagram Sistem Keseluruhan}

Diagram blok sistem memberikan gambaran sistem inkubator bayi prematur secara keseluruhan. Pada diagram blok sistem terdiri dari mikrokontroler arduino, sensor DS18B20, load cell, sensor detak jantung, lampu pijar, kipas DC, LCD, kamera, NodeMCU ESP8266, dan android. Untuk gambar blok diagram sistem keseluruhan dapat dilihat Gambar 9.

Berdasarkan Gambar 9 diagram blok sistem dapat dijelaskan sistem monitoring inkubator bayi prematur. Pada Gambar 9 diagram blok terdapat 3 input yaitu sensor suhu, sensor berat dan sensor detak jantung . Input sensor suhu berfungsi untuk pembacaan suhu di dalam inkubator bayi. Input berat berfungsi sebagai timbangan badan bayi yang di letakkan pada inkubator bayi. Input sensor detak jantung berfungsi untuk pembacaan detak jantung bayi didalam inkubator. Gambar 3.1 diagram blok sistem terdapat bagian mikrokontroller arduino, dan output yang terdiri dari LCD, kipas DC, dan lampu pijar. Pada bagian mikrokontroler menggunakan arduino yang merupakan suatu unit untuk mengontrol dan memprogram perancangan secara keseluruhan. Pada kipas DC dan lampu pijar merupakan output untuk mengatur suhu di dalam inkubator agar tetap stabil. 


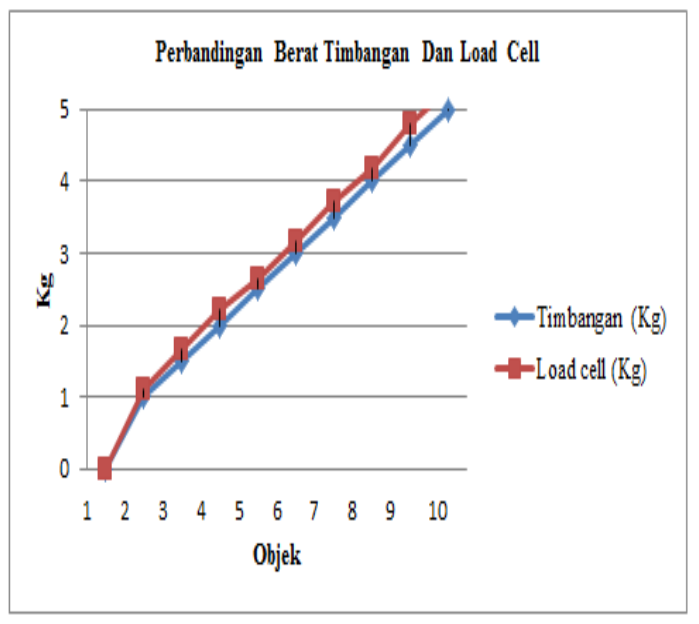

Gambar 13. Grafik Perbandingan Pengukuran Berat Badan dengan Alat Ukur dan Load Cell

TABEL 4

HASIL PENGUJIAN SENSOR DS18B20

\begin{tabular}{|c|c|c|c|}
\hline No. & $\begin{array}{c}\text { Sensor } \\
\text { DS18B20 } \\
\left(\text { Suhu }^{\circ} \mathrm{C}\right)\end{array}$ & $\begin{array}{c}\text { Termometer } \\
\left(\text { Suhu }^{\circ} \mathrm{C}\right)\end{array}$ & $\begin{array}{c}\text { Galat } \\
\text { Relatif } \\
\text { Suhu } \\
(\%)\end{array}$ \\
\hline 1. & 31,4 & 31,8 & 1,27 \\
\hline 2. & 31,5 & 31,9 & 1,26 \\
\hline 3. & 31,6 & 32 & 1,26 \\
\hline 4. & 31,7 & 32 & 0,94 \\
\hline 5. & 31,8 & 32,2 & 1,25 \\
\hline 6. & 31,8 & 32,2 & 1,25 \\
\hline 7. & 31,8 & 32,2 & 1,25 \\
\hline 8. & 31,8 & 32,2 & 1,25 \\
\hline 9. & 31,9 & 32,4 & 1,56 \\
\hline 10. & 32 & 32,4 & 0,31 \\
\hline \multicolumn{3}{|c|}{ Rata-rata error } & 0,10 \\
\hline
\end{tabular}

\section{HASIL DAN PEMBAHASAN}

\section{A. Pengujian Sensor}

\section{Pengujian Load cell}

Pengujian load cell digunakan untuk menguji kondisi, sensitivitas dan karakteristik sensor dalam mendeteksi objek yang diukur untuk mengetahui bahwa sensor bekerja dengan baik atau tidak. Dengan mengukur resistansi saat ada beban dan tanpa beban. Pengujian load cell yang digunakan sebagai alat ukur berat badan.

Pengujian dilakukan dengan menggunakan 10 variasi berat dengan objek yang berbeda-beda. Pengujian dilakukan dengan pengukuran menggunakan alat ukur dan dengan load cell. Hasil Pengujian dapat dilihat pada Tabel 3.

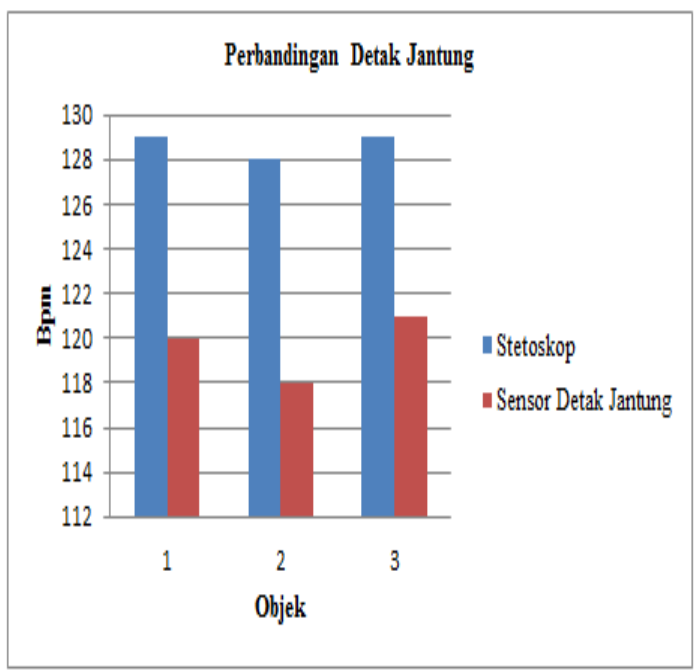

Gambar 14. Grafik Perbandingan Sensor Detak Jantung dan Stetoskop

Berdasarkan Tabel 3 pengujian load cell menggunakan berbagai variasi berat benda menunjukan hasil yang berbeda, perbedaan terkecil terjadi pada objek ke-2 dan perbedaan terbesar terjadi pada objek ke-9. Pengujian ini dilakukan untuk mengetahui tingkat keakurasian load cell dengan perbandingan menggunakan timbangan digital.

Dari Tabel 3 dapat dilihat nilai berat badan yang terukur dari load cell terhadap alat ukur. Dapat dilihat perbandingan antara pengukuran menggunakan load cell dan dengan menggunakan alat ukur. Perbandingan berat badan terukur dengan load cell dan alat ukur juga dapat dilihat dalam bentuk grafik seperti pada Gambar 13.

Berdasarkan Gambar 13 terlihat grafik perbandingan yang menunjukkan selisih antar pengukuran berat badan. Dapat dilihat bahwa pada beberapa objek memiliki selisih yang cukup besar. Pada pengukuran yang dilakukan, semakin besar berat badan maka memiliki selisih yang kecil.

\section{Pengujian Sensor Detak Jantung}

Pulse heart Sensor merupakan sensor untuk mendeteksi denyut jantung, dalam hal ini pulse heart sensor digunakan untuk mendeteksi denyut jantung bayi. Sensor mempunyai 3 buah pin yang difungsikan berbeda. Pin 1 digunakan sebagai pin data yang terhubung ke pin A0 pada mikrokontroler. Pin 2 digunakan sebagai sumber daya Vcc dan Pin 3 digunakan sebagai Ground. Hasil Pengujian dapat dilihat pada Tabel 5.

Berdasarkan Tabel 5 pengujian sensor detak jantung dengan menggunakan beberapa bayi untuk menjadi sample. Dilihat pada tabel data yang diukur menggunakan sensor dan alat medis mengalami perbedaan angka yang besar. 
TABEL 6

HASIL PENGUJIAN ALAT KESELURUHAN

\begin{tabular}{ccc}
\hline $\begin{array}{c}\text { Pengujian } \\
\text { Ke- }\end{array}$ & $\begin{array}{c}\text { Jarak NodeMCU } \\
\text { Android }\end{array}$ & Komunikasi \\
& (Meter) & \\
\hline 1. & 5 & Terhubung \\
2. & 10 & Terhubung \\
3. & 15 & Terhubung \\
4. & 20 & Terhubung \\
5. & 25 & Terhubung \\
6. & 30 & Terhubung \\
7. & 35 & Terhubung \\
8. & 40 & Terhubung \\
9. & 45 & Terhubung \\
10. & 50 & Terhubung \\
11. & 55 & Terhubung \\
12. & 60 & Terputus \\
\hline
\end{tabular}

\begin{tabular}{ccc}
\hline $\begin{array}{c}\text { Pengujian } \\
\text { Ke- }\end{array}$ & $\begin{array}{c}\text { Jarak Kamera } \\
\text { dan Android }\end{array}$ & Komunikasi \\
\hline 1. & 5 & \\
\hline 2. & 10 & Terhubung \\
3. & 15 & Terhubung \\
4. & 20 & Terhubung \\
5. & 25 & Terhubung \\
6. & 30 & Terputus \\
7. & 35 & Terputus \\
8. & 40 & Terputus \\
9. & 45 & Terputus \\
10. & 50 & Terputus \\
11. & 55 & Terputus \\
12. & 60 & Terputus \\
\hline
\end{tabular}

Dari Tabel 5 dapat dilihat nilai sensor detak jantung yang terukur dari Pulse Heart Sensor terhadap stetoskop. Dapat dilihat perbandingan antara pengukuran menggunakan pulse heart sensor dan stetoskop. Perbandingan detak jantung terukur dengan pulse heart sensor dan stetoskop juga dapat dilihat dalam bentuk grafik seperti pada Gambar 14.

Berdasarkan Gambar 4.2 terlihat grafik perbandingan yang menunjukkan selisih antara pengukuran detak jantung dan Stetoskop. Dapat dilihat bahwa pada beberapa objek memiliki selisih yang cukup besar.

\section{Pengujian Aplikasi ThingShow Android}

Pengujian dilakukan dengan menggunakan android Xiaomi 4A. Tampilan pengujian aplikasi thingshow android dapat dilihat pada Gambar 15.
TABEL 7

PENGUJIAN SENSOR SUHU PADA BAYI

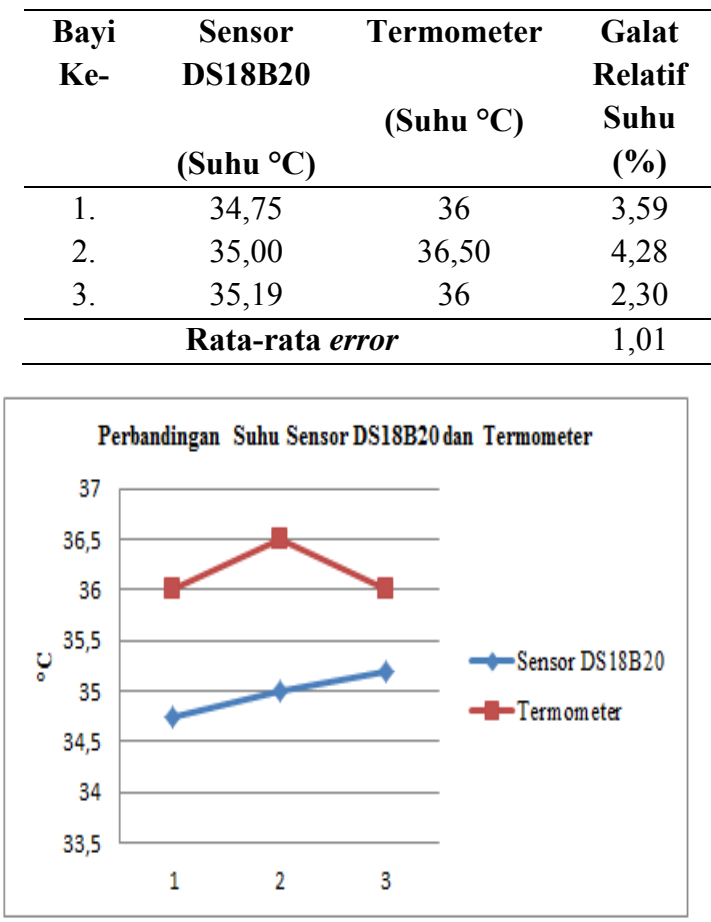

Gambar 15. Grafik Perbandingan Sensor DS18B20 dan Termometer

Gambar 15 merupakan tampilan channel keseluruhan aplikasi ThingShow pada android. Dalam aplikasi thingshow ini terdapat channel monitoring inkubator untuk bayi 1, bayi 2 dan bayi 3 yang telah dibuat pada website thingspeak, untuk masuk kedalam channel monitoring inkubator pada thingshow dengan cara login menggunakan Channel ID dan API KEY yang sudah didapat dari website www.thingspeak.com. Hasil tampilan channel monitoring inkubator untuk bayi 1, 2 dan 3 thingshow android dapat dilihat pada Gambar 16.

Gambar 16 merupakan tampilan data Channel monitoring inkubator bayi 1, 2 dan 3 thingshow pada android. Dapat dilihat pada tampilan thingshow ada tiga parameter yang akan dimonitoring yaitu suhu, detak jantung (Bpm) dan berat badan. Untuk data suhu dan detak jantung ditampilkan dalam bentuk grafik sedangkan data berat badan ditampilkan dalam bentuk angka.

\section{Pengujian Sistem Secara Keseluruhan}

Pengujian sistem secara keseluruhan dilakukan untuk mengetahui respon parameter (DS18B20, Load Cell, Pulse Heart Rate Sensor) bekerja dengan baik saat digunakan secara bersamaan. Sistem keseluruhan dibagi menjadi 2 yaitu sistem monitoring thingshow android dan sistem monitoring kamera.

Sistem monitoring thingshow android memiliki beberapa parameter yaitu sensor DS18B20 sebagai 
pembaca suhu dan Pulse Heart Rate Sensor sebagai pembaca detak jantung, Modul WiFi NodeMCU sebagai penghubung dengan website thingspeak dan aplikasi thingshow android, Arduino mega sebagai mikrokontroler. Hasil sistem kerja alat secara keseluruhan dapat dilihat pada Gambar 17.

Pada perancangan alat di sistem monitoring thingshow android adalah sesuai dengan pengujian perkomponen yang telah dilakukan maka akan dilakukan penyatuan komponen agar sistem dapat berjalan sesuai dengan yang diingikan. Pada sistem monitoring thingshow android terdapat sensor DS18B20 yang berfungsi sebagai pembaca suhu inkubator. Pulse Heart Rate sensor yang berfungsi untuk pembaca detak jantung. Load cell yang berfungsi untuk pembaca berat badan bayi. Modul WiFi NodeMCU akan selalu mengirimkan data pembacaan sensor ke website thingspeak dan kemudian dikirim ke aplikasi thingshow android. Pada sistem monitoring kamera komponen yang digunakan adalah kamera Kogan 4K akan digunakan untuk memonitoring keadaan tabung inkubator dan akan ditampilkan android dengan menggunakan aplikasi GoPlus Cam.

Berdasarkan beberapa pengujian tersebut maka didapat data hasil pengujian alat keseluruhan seperti pada Tabel 6.

Data hasil pengujian Tabel 6 memperlihatkan bahwa sistem mampu menjalankan tugas sesuai dengan diagram alir yang telah dirancang. Pada percobaan ke-1 sampai dengan percobaan ke-11 jarak modul WiFi dan android masih terhubung, namun pada percobaan ke-12 dengan jarak 60 meter koneksi terputus. Pada percobaan ke-1 sampai dengan 9 jarak kamera dengan android masih terhubung dan pada percobaan ke-10 sampai dengan percobaan ke-12 dari jarak 50 meter, 55 meter dan 60 meter koneksi terputus. Maka dari percobaan yang dilakukan dapat disimpulkan bahwa sistem secara keseluruhan dapat berjalan dengan baik sesuai dengan yang diingikan.

\section{IV.PENUTUP}

\section{A. Kesimpulan}

1. Penerapan sistem monitoring inkubator bayi prematur secara real time dengan menggunakan android tidak berjalan sesuai dengan yang diinginkan, karena memiliki delay waktu sebesar 10-15 detik.

2. Pengaplikasian android sebagai sistem monitoring jarak jauh menggunakan kamera dilakukan dengan aplikasi GoPLus Cam. Aplikasi GoPlus Cam android dan kamera memiliki jarak koneksi maksimum yaitu jarak $15 \mathrm{~m}$.

3. Pengaplikasian android sebagai tampilan output suhu, detak jantung dan berat badan ditampilkan menggunakan aplikasi thingshow. Aplikasi thingshow menampilkan pembacaan data suhu dan detak jantung dalam bentuk grafik sedangkan pembacaan berat badan ditampilkan dalam bentuk angka dan berhasil ditampilkan pada android.

\section{B. Saran}

1. Ketika melakukan pengukuran detak jantung sebaiknya meminimalisir gerakan, hal ini disarankan karena pulse heart rate sensor sangat sensitive terhadap gerakan.

2. Penggunaan load cell sebagai pengukur berat badan sebaiknya menghindari penggunaan kabel yang terlalu panjang, karena resisitansi kabel bisa menghambat perubahan arus dan tegangan yang terukur.

3. Penggunaan lampu pijar 5 watt sebagai elemen pemanas untuk pemanas suhu dalam inkubator sebaiknya diganti menggunakan elemen pemanas lain atau dengan lampu pijar daya yang lebih dari 5 watt.

4. Untuk selanjutnya alat ini dibuat penambahan sensor kadar oksigen agar dapat mengetahui kadar oksigen dalam tabung inkubator.

5. Untuk kualitas kamera agar diganti dengan kualitas yang lebih bagus karena jarak monitoring kamera yang digunakan hanya $15 \mathrm{~m}$.

\section{REFERENSI}

[1] Aswan, Ilham. 2017. Rancang Bangun Sistem Pengontrolan Suhu Inkubator Bayi dan Sistim Monitoring Bagi Bayi didalam Inkubator Berbasis Mini Pc. Padang: Politeknik Negeri Padang.

[2] Dwi Setyaningsih N.Y, Murti Alif Catur. 2016. Control Temperature On Plant Baby Incubator With Fuzzy Logic. Kudus : Universitas Muria Kudus.

[3] Intan Ramadhani, Yenisa. 2017. Prototype Monitoring dan Pengontrolan Suhu Inkubator Bayi menggunakan Smartphone Berbasis Mikrokontroler. Padang: Politeknik Negeri Padang.

[4] Nur Sultan. Salahuddin, Aryanti Febri, dkk. 2014. Sistem Pemantau Bayi Prematur Melalui Nirkabel. Depok: Universitas Gunadarma.

[5] Daniel Priyo Yuwono, Budhi Kristianto. 2013. Perancangan Sistem Aplikasi Monitoring Suhu Dan Kelembapan Inkubator Bayi Berbasis LAN. Salatiga: Universitas Kristen Satya Wacana.

[6] Arjun, Budi. 2014. Sistem Komunikasi Digital atau Modul Dasar Telkom. Medan: Universitas Sumatra Utara.

[7] Theopaga Adhi Ksatria, Rizal Ahmad. 2014. Desigen and Implementation Of PID Control Based Baby Incubator. J. Theor. Appl. Inf. Technol, pp.19-24.

[8] M.R. Apriyadi. 2012. Miniatur Pemantau Suhu Inkubatot Berbasis Mikrokontroler Atmega 8535 dan Jaringan Nirkabel. Yogyakarta: Universitas Gunadarma.

[9] Budiona. 2012. Desain dan Pembuatan Inkubator Berdasarkan Distribusi Temperatur. J. GAMMA, vol. 2086-3071, pp. 140-147.

[10] Kurniawan Eka Puji, Hantoro Ridho, dan Gunawan Nugraha. 2013. Pengarauh Jarak Antar Dinding Terhadap Distribusi Temperatur Pada Inkubator Bayi Berdinding Ganda. Surabaya: Institut Teknologi Sepuluh November. 
[11] Sugihatmoko Jefry, Purwanto, Rahmadawati.2008. Aplikasi Kontroler PID dalam Pengendalian Suhu Inkubator Bayi Prematur Berbasis Mikrokontroler ATMega2560. Malang: Universitas Brawijaya.

[12] Sugihatmoko Jefry, Purwanto, Rahmadawati.2008. Aplikasi Kontroler PID dalam Pengendalian Suhu Inkubator Bayi Prematur Berbasis Mikrokontroler ATMega2560. Malang: Universitas Brawijaya.

[13] Negara Yuda Prawira. 2014. Alat Pengukur Kelembaban dan Suhu Menggunakan Sensor DHT11. Bogor: Universitas Pakuan Bogor.

[14] Assa'idah dan Yulinar Adnan. 2009. Investigasi Terhadap Kemampuan 2 Tipe ADC. Volume 12 Nomer 2(B) 12205 6-7.

[15] Beekman, George. 2011. Digital Planet: Tomorrow's Technology and You, Introductory (10 ${ }^{\text {th }}$ Edition). London: Pearson.

[16] Setiawan, Iwan. Andjarwirawan, Justinus. Handojo, Andreas. 2012. Aplikasi Makassar Tourism pada Kota Makassar Berbasis Android. Surabaya: Universitas Kristen Petra.

[17] Rifai, Dwi Aziz. 2019. Alat Penghitung Biaya Pemakaian Air Rumah Menggunakan NodeMCU ESP8266 Berbasis IoT(Internet Of Things). Lampung: Skripsi, Program Studi Teknik Elektro, Fakultas Teknik, Universitas Lampung.
[18] Sari, Novika. 2019. Perancangan Prototype Sistem Pengatur Suhu Inkubator Bayi Berdasarkan Umur dan Berat Badan Bayi Menggunakan Fuzzy Logic Control. Bengkulu: Skripsi, Program Studi Teknik Elektro, Fakultas Teknik, Universitas Bengkulu.

[19] Puji, Aprinda. 2020. Detak Jantung Normal Manusia dan Cara Menghitungnya. http:/hellosehat.com/hidupsehat/tips-sehat/cara-hitung-detak-jantung/\#gref $\quad(\mathrm{Di}$ Akses Tanggal 28 November 2020).

[20] Jaka. 2017. Review XiaomiRedmi 4A http://jalantikus.com/gadget/review-xiaomi-redmi-4a/ (Di Akses Tanggal 31 Oktober 2020).

[21] Milenium, Plaza. 2018. Kogan Ultra Hd Putih Action Camera. Hhtp://www.blibli.com/p/kogan-4k-ultrahdputih-action-camera-wifi-16mp-/ps-BUP-60026-00001 (Di Akses Tanggal Oktober 2020).

[22] Ghunkhalifah10. 2015. Pulse Heart Rate Sensor Detak Jantung Analog ArduinoUno R3 Nano Mega. https://shopee.co.id/Pulsesensor-Pulse-Heart-RateSensor-Detak-Jantung-Analog-Arduino-Uno-R3-nanoMega-i.3945646.1190744041 (Di Akses Tanggal 31 Oktober 2020). 